\title{
An ACCOUnT OF DROSERA SECTION LASIOCEPHALA
}

\author{
RICHARD NUNN・New South Wales•Australia・richardjnunn1@gmail.com \\ AlLEN LOWRIE •Western Australia • Australia・allen.lowrie@bigpond.com
}

\begin{abstract}
Over the past two decades interest has grown in the tropical Drosera of northern Australia. As more botanical research is conducted in this remote region, new species have been described, new undescribed taxa discovered and we have gained a greater understanding of their ecology. Lowrie (1998) provided the first detailed account of Drosera section Lasiocephala, additional accounts were published in Lowrie (2014) and Lowrie et al. (2017), since then further field work has been undertaken, phylogenetic studies (Fleischmann et al. 2018), and a new species has been described (Baleeiro et al. 2020). The aim of this paper is to synthesize the current body of knowledge into the most up to date summary of this section, and draws extensively on previous text created by the authors (Lowrie 1998; Bourke \& Nunn 2012; Lowrie 2014; Lowrie et al. 2017), with the addition of new studies (Fleischmann et al. 2018; Baleeiro et al. 2020) and many new images.
\end{abstract}

\section{Introduction}

Drosera section Lasiocephala Planchon inhabits far northern Australia in a band that stretches from the Kimberley in the west through the northern part of the Northern Territory and northern Queensland, from north of Cairns to the tip of Cape York, extending across the islands of the Torres Strait and into southern coastal Papua New Guinea. This section comprises the perennial petiolaris complex species and two erect annual species, the type species for this section is Drosera petiolaris R.Br. ex DC.

\section{Botanical history}

Drosera is the largest carnivorous plant genus with ca. 250 species known worldwide, 147 of which are endemic to Australia (Lowrie 2014; Fleischmann et al. 2018). The majority of Drosera species are perennial herbs, including 14 of the 16 currently recognised species of Drosera section Lasiocephala, the other two being annual, which sits within Drosera subgenus Ergaleium per the infrageneric classification of Fleischmann et al. (2018).

The first species described from Drosera section Lasiocephala were Drosera petiolaris R.Br. ex DC. and D. banksii R.Br. ex DC in 1824 (de Candolle 1824). The type specimens of D. petiolaris and $D$. banksii were collected in 1770 by Banks and Solander on the Captain James Cook's voyage aboard the HMS Endeavour. They were collected at the Endeavour River, Cooktown, Queensland. Drosera fulva Planch. was described in 1848, from a collection by John W. Armstrong sometime between 1838 and 1840, in the region of Port Essington (175 km northeast of Darwin). Diels (1906) treated $D$. fulva as a synonym of $D$. petiolaris and subsequent authors supported this until Lowrie reinstated this species in 1998 (Lowrie 1998). Marchant and George (1982) described D. subtilis in Flora of Australia, from material collected in 1980 from the Mitchell Plateau. Katsuhiko Kondo (1984) formally described three closely related additional taxa, D. dilatatopetiolaris, D. falconeri, and D. lanata. Lowrie undertook a significant amount of research into the $D$. petiolaris complex in the 1990's and described a further eight species from across northern Australia (Lowrie 1994, 
1996a, 1996b, 1997, 1998, 2014). The most recent addition to Drosera section Lasiocephala was in 2020 when D. stipularis was described from Far North Queensland (Baleeiro et al. 2020).

The section name Lasiocephala is derived from the Greek lasios (shaggy) and kephale (head), a reference to densely hairy growing points. These species were originally placed in Drosera subgenus Rorella sect. Lasiocephala Planch. (Planchon 1848). In a recent classification, section Lasiocephala was included under subgenus Drosera (Seine \& Barthlott 1994), however Fleischmann et al. (2018) placed this section in $D$. subgenus Ergaleium, which includes the majority of Australian taxa, and this placement is supported in this paper. The erect annual species D. banksii and D. subtilis, were formerly included in D. section Annuerecta Lowrie (Lowrie 2014) and sect Ergaleium (Marchant \& George 1982) are here included in D. section Lasiocephala on account of new phylogenetic data (Fleischmann et al. 2018) supporting this placement.

\section{Species roster - etymology, distribution, habitat, and phenology}

There are currently 16 published species in Drosera section Lasiocephala and at least 8 new species awaiting formal description (Lowrie 2014; Lowrie et al. 2017; Baleeiro et al. 2020).

\section{Drosera banksii R.Br. ex DC (Fig. 1A)}

The epithet banksii honours Sir Joseph Banks (1743-1820), a famous patron of the natural sciences and President of the Royal Society for over 40 years who sailed around the world with Captain James Cook (1768-1771). Drosera banksii has a northern distribution in Western Australia (Packhorse Range; Beverley Springs Station); Northern Territory (Humpty Doo; Kakadu) and Queensland (Endeavour River). It is also recorded from western Papua New Guinea. This species grows in red loam by creeks, on sandy creek banks in black sand, and on watersheds near sandstone rock outcrops. This species flowers from May to July.

\section{Drosera brevicornis Lowrie (Fig. 1C)}

The epithet brevicornis is derived from the Latin brevis (short) and cornis (horned), in reference to the horn-like apical filament projection above the anthers. Mainly known from Northern Territory where, on the mainland, D. brevicornis is recorded from the Darwin region, notably Palmerston to Batchelor, south of Darwin, and eastwards towards and including Kakadu National Park. In Queensland, it is known from Sweers Island in the Gulf of Carpentaria. Drosera brevicornis grows on gravel slopes in hilly areas, or in shallow depressions in flat country, predominantly in the slower moving watershed zones where sand and loam particles can accumulate amongst the gravel. This species flowers from March to April.

\section{Drosera broomensis Lowrie (Fig. 1D)}

The epithet broomensis refers to the Broome region in the Kimberley, Western Australia, where this species occurs. Drosera broomensis is known from the Kimberley, Western Australia, where it is apparently confined to the Dampier Peninsula. This species is commonly found in soils that also have an association with beige coloured termite mounds. It grows in sandy soils amongst thinly spread, annual cane grass (Mnesithea rottboellioides) on bare patches of ground that border seasonally wet depressions and lake shores to the north and northeast of Broome. This species flowers from February to March.

\section{Drosera caduca Lowrie (Fig. 1E)}

Drosera caduca is named from the Latin caducus (fallen or liable to fall), a reference to the traps that are present only on the early season growths, but reduced and eventually absent on all subse- 

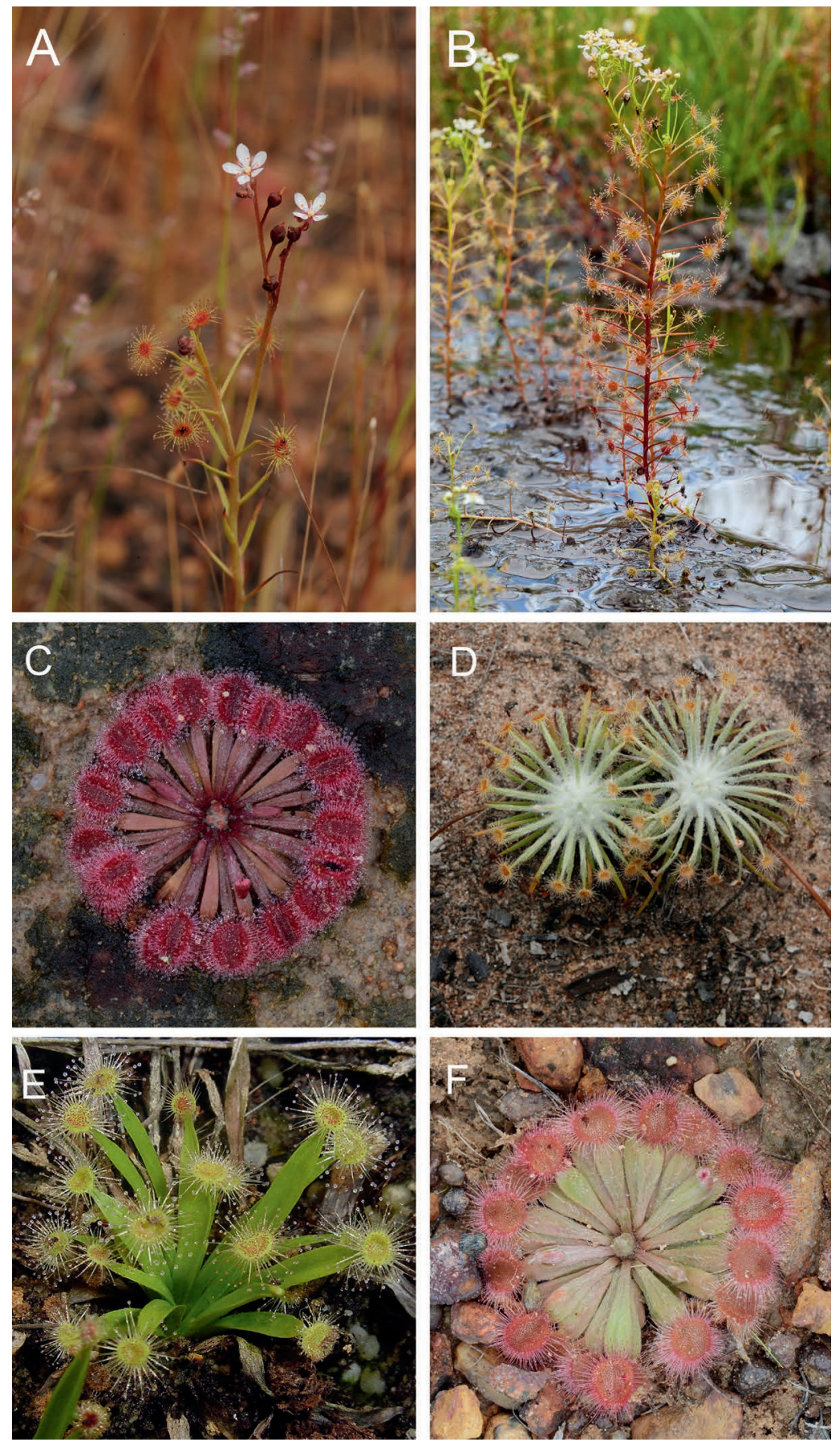

Figure 1: A: Drosera banksii; B: D. subtilis; C: D. brevicornis; D: D. broomensis; E: D. caduca; F: D. darwinensis. Photos: A, C, F - R. Nunn; B - A. Robinson; C - G. Bourke; E - A. Lowrie. 
quent leaves. Drosera caduca is distributed throughout the Edkins Range to the southern regions of the Prince Regent River Reserve. It also occurs on Augustus Island, Kimberley, Western Australia. On the mainland, it grows on creek margins in silty white sand soils. On Augustus Island, it grows in stony brown sand on the edge of a basin on the lower slopes of a sandstone ridge with Eucalyptus miniata woodland and Spinifex. This species flowers from December to July.

\section{Drosera darwinensis Lowrie (Fig. 1F)}

The epithet darwinensis refers to the Darwin region of the Northern Territory, where this species occurs. Drosera darwinensis is distributed from Palmerston to Berry Springs, south of Darwin, and eastwards to Humpty Doo in the Northern Territory. It grows in clayey-sand with laterite pebbles. This species flowers in December to April

\section{Drosera derbyensis Lowrie (Fig. 2A)}

The epithet derbyensis refers to the Derby region in the Kimberley, Western Australia, where this species was discovered growing near the Boab Prison Tree, near Derby, in 1988. Drosera derbyensis is known from Western Australia and is a common species on the Yampi Peninsula, as well as on a number of the off-shore islands in the Buccaneer Archipelago to the northwest of the peninsula. Drosera derbyensis also extends south of the Yampi Peninsula to the Erskine Ranges, and to the southeast to the Leopold Ranges. Drosera derbyensis grows in sandy soils on the aprons of sandstone rock outcrops, as well as in seasonally wet savannahs. This species flowers in March to June.

\section{Drosera dilatatopetiolaris K.Kondo (Fig. 2B)}

The epithet dilatatopetiolaris is from the Latin dilatatus (enlarged, widened) and petiolus (petiole), in reference to the wider leaves of this species in comparison to the narrower leaves of Drosera petiolaris. This species ranges widely from the Kimberley in Western Australia and east to the Darwin region. There are official records from Beverley Springs and King Edward River, while in Northern Territory there are records from Palmerston and Humpty Doo. This species grows in sandy soils that are damp but not flooded during the wet season, favouring sandy flats near sandstone outcrops, Eucalyptus savannahs, and open mixed woodlands. This species flowers in October.

\section{Drosera falconeri K.Kondo (Fig. 2C; Front Cover)}

The epithet falconeri honours Mr. D. Falconer, a tropical aquarium fish collector in the Northern Territory, who first discovered this species whilst on a fish-collecting expedition to the Finniss River. This species occurs in Northern Territory, with records from Palmerston, Berry Springs, Fly Creek, the Finniss River catchment, and Melville Island. It grows in grey, silty clay, often on gently sloping savannah in areas that are inundated for periods of time, especially during the earlier part of the wet season. This species flowers in November to December.

\section{Drosera fulva Planch. (Fig. 2D; Back Cover)}

The epithet fulva is from the Latin fulvus (reddish yellow or tawny brown), in reference to the colour of the pressed herbarium specimens on the type sheet. Records of this species all come from the Northern Territory, including Howard Springs, Palmerston, Humpty Doo, and Port Essington on the Cobourg Peninsula. It grows in sandy soil on damp flats, seepage areas and ephemeral wet depressions just above the wet season flood levels. If heavy rains and flooding are experienced, plants may remain under water for several weeks at a time. This species flowers in February to May. 

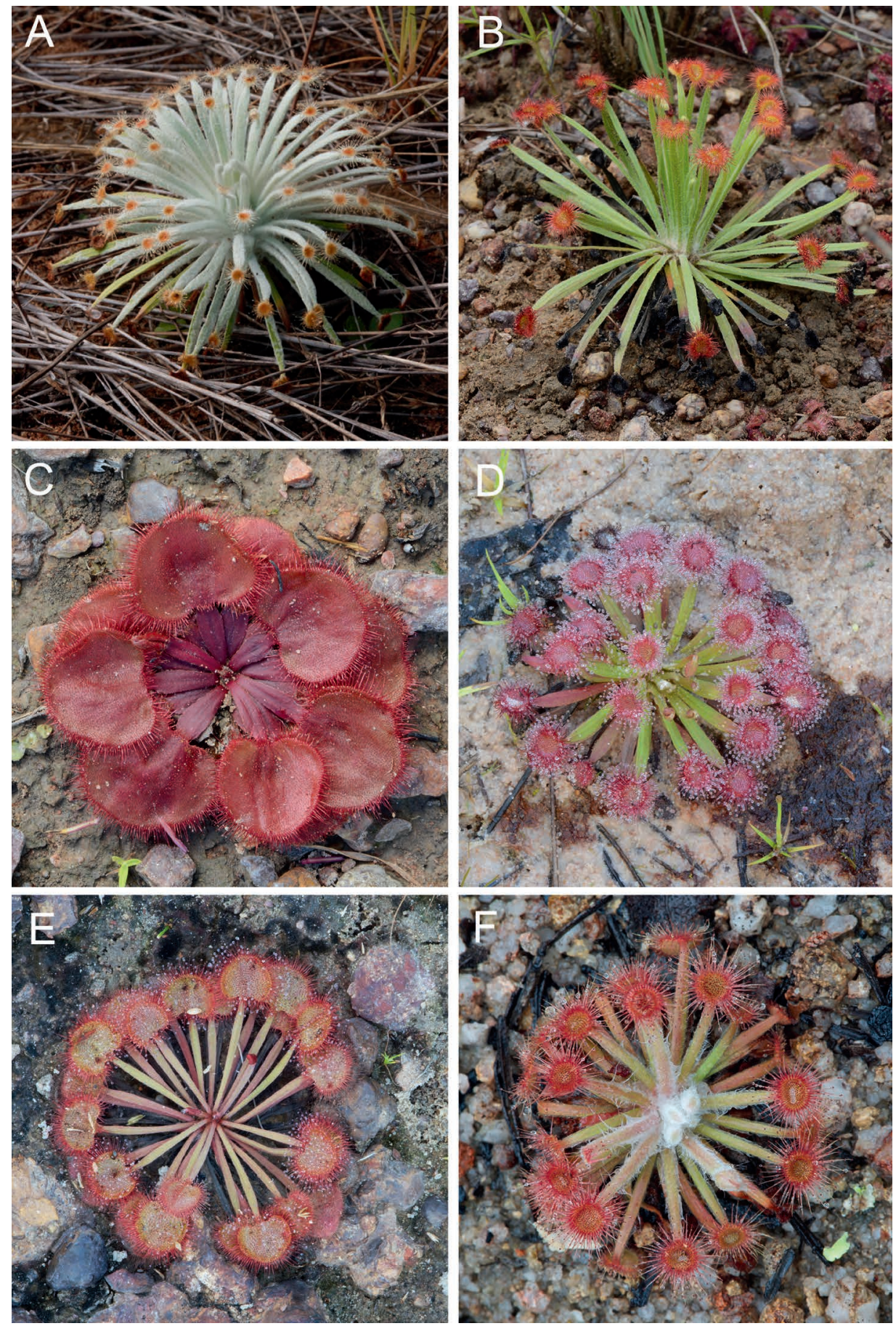

Figure 2: A: Drosera derbyensis; B: D. dilatatopetiolaris; C: D. falconeri; D: D. fulva; E: D. kenneallyi; F: D. lanata. Photos: A - G. Bourke; B-F-R. Nunn 


\section{Drosera kenneallyi Lowrie (Fig. 2E)}

The epithet kenneallyi honours Professor Kevin Francis Kenneally, Botanist and Principal Research Scientist, who first collected this species on 7 December 1982. Drosera kenneallyi is known from Western Australia, with records from the Mitchell Plateau area of the Kimberley region, and the Northern Territory, with records from Dundee Beach. The type material was collected in skeletal soil over hardpan laterite near Airfield swamp. In the Northern Territory it grows in silty sand soils over laterite in association with grey, magnetic termite mounds. This species flowers in November to early December.

\section{Drosera lanata K.Kondo (Fig. 2F)}

The epithet lanata is from the Latin lanatus (woolly), a reference to its very dense, woolly indumentum. Drosera lanata is endemic to Queensland, with records from Mareeba, Chewko, and Undarra. It grows in sandy or gravelly well-drained soils in woodlands or in shallow, decomposed granite in rocky areas, often in open Casuarina woodland. In the Mareeba region on the Atherton Tablelands, it favours well-drained white sand habitats. This species flowers in January to March.

\section{Drosera ordensis Lowrie (Fig. 3A)}

The epithet ordensis refers to the alluvial valley of the Ord River, in which this species grows. Drosera ordensis is known from Western Australia, with records from Kununurra, Wyndham, Mount Elizabeth Station, and Pago, as well as the Northern Territory (Keep River National Park). Drosera ordensis grows in sandy soils derived from sandstone rock. Large colonies of plants are commonly found near banded sandstone outcrops. This species flowers in December to April.

\section{Drosera paradoxa Lowrie (Fig. 3B)}

The epithet paradoxa is from the Greek paradoxos (contrary to expectation), referring to the complicated and poorly understood growth cycle of this species, which was only revealed after considerable field study over a number of years during the wet and dry seasons. Drosera paradoxa is widely distributed in Western Australia from the west and north coasts of the Kimberley, inland to Beverley Springs, and eastwards to Arnhem Land and Kakadu National Park in the Northern Territory. Drosera paradoxa grows in skeletal, sandy soils over sandstone pavements on the banks, as well as beds, of seasonally dry creeks, in the cracks of sandstone pavements, in pads of moss adjacent to sandstone seepages, as well as amongst sandstone boulders. Flowers March to May.

\section{Drosera petiolaris R.Br. ex DC (Fig. 3C)}

The epithet petiolaris is from the Latin petiolus (petiole) and -aris (provided with), in reference to the long, narrowly petiolate leaves of this species. This species is recorded from Queensland (Endeavour River to Cooktown, Musgrave, Sanamere, Lockhart River) and the southern coastal plain of the island of New Guinea. It grows in sand near creeks and pools, particularly around sedge, as well as open wet scrub. It is commonly found standing in shallow water during the wet season. This species flowers in October to April.

\section{Drosera stipularis Baleeiro, R.W.Jobson and R.L.Barrett (Fig. 3D)}

The specific epithet refers to the erect to spreading stipules exserted above the central rosette. Known only from two collections north of Cooktown and east of Starke National Park, on Cape York Peninsula, Queensland. Found on moist pockets (each pocket c. $20 \mathrm{~m}^{2}$ ) of fine sand substrate within low heath and sedges. Found in flower in April and July. 

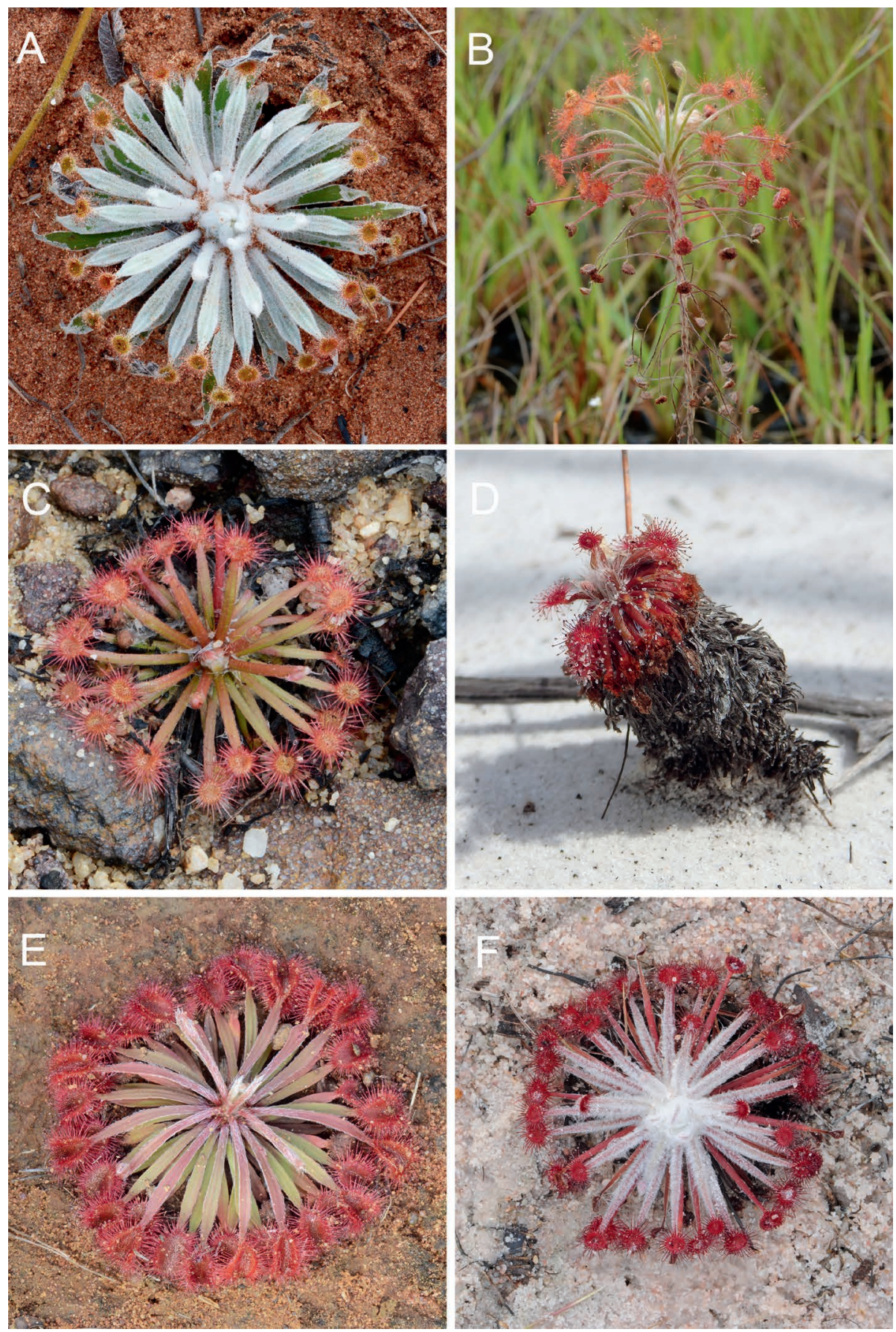

Figure 3: A: Drosera ordensis; B: D. paradoxa; C: D. petiolaris; D: D. stipularis; E: D. aff. brevicornis from Kimberley; F: D. aff lanata from NT. Photos: A,B,C,E,F-R. Nunn; D - P. Baleeiro. 
Drosera subtilis N.G.Marchant (Fig. 1B)

The epithet subtilis is derived from the Latin subtilis (fine, delicate), in reference to its somewhat slender overall form. Drosera subtilis is known from Western Australia, where it is widespread throughout the Kimberley region, with records from Beverley Springs Station, Bigge Island, the Mitchell Plateau (Camp Creek), and Theda Station. It has also been recorded in the Northern Territory (Little Nourlangie Rock). It grows in skeletal soils of sand and black humus over sheet sandstone, in areas covered with a film of water such as that found on the margins of seepage lines. It also grows in wet, black mud on the edges of sheet basalt, and in gravel in the seepage lines of basalt pavements. This species flowers in October to April.

\section{Undescribed Taxa}

Lowrie (2014) included another eight new taxa that are currently in the process of being described. Many of these are now in cultivation and readers may ask why they haven't been formally described by now. Describing plants from cultivated specimens is a poor practice, as it will never lead to a description that accurately expresses the variation of the species exhibited in the field. The use of cultivated specimens for type specimens should also be discouraged for the same reason. The naming of new species should rest with those botanists who collect specimens and study plants in the field as well as in the herbarium. It is only in the plant's natural habitat that the biology of the species can be closely examined and educated judgments be made about its uniqueness. Once the field data have been examined and comparisons made with known species, the process of naming a new species can properly begin. The naming of new species is time consuming and arduous. The task must be done thoroughly into order to have any scientific merit. Specimens of related species must be examined and much of this material is difficult to obtain from the field. The complete life cycle of each proposed species must be examined so that comparisons can be made with its nearest relatives. The majority of the northern regions of Australia are remote and lack roadways, and travel in the wet season in most areas is logistically impossible without the aid of a helicopter. The northern regions of tropical Australia are poorly explored botanically, and it is certain that additional new species will continue to be discovered in the coming years. These eight taxa are as follows.

\section{Drosera species from Bigge Island (Fig. 4D)}

This tiny, prop-rooted, rosetted species bearing long peduncles and a many-flowered rachis is yet another example of a new species being collected from a region that has previously been poorly botanically explored. It was discovered during a botanical survey on the uninhabited Bigge Island off the Australian mainland and growing in sandy soils between Triodia (Spinifex) species.

\section{Drosera species from Tanami Desert (Fig. 4F)}

This is an arid growing, hairy leaved, white flowered, $50 \mathrm{~mm}$ diameter, basal rosetted species from the Tanami Desert in the Northern Territory and the adjoining Great Sandy Desert region of Western Australia. It grows in the open sandy soils between Triodia species (Spinifex bushes) and the Acacia species shrubs of these desert regions. Although they are deserts in name, they do still receive their fair share of rain events at different times of the year via thunderstorms as well as regular morning fogs.

\section{Drosera aff. brevicornis from Kimberley (Fig. 3E)}

A large, compact, wide leaved, rosetted species with large white flowers that develop huge mature and immature seed capsules. Known from the Mitchell Plateau, Theda, as well as occurring off shore on Augustus Island in the Kimberley region of Western Australia. 

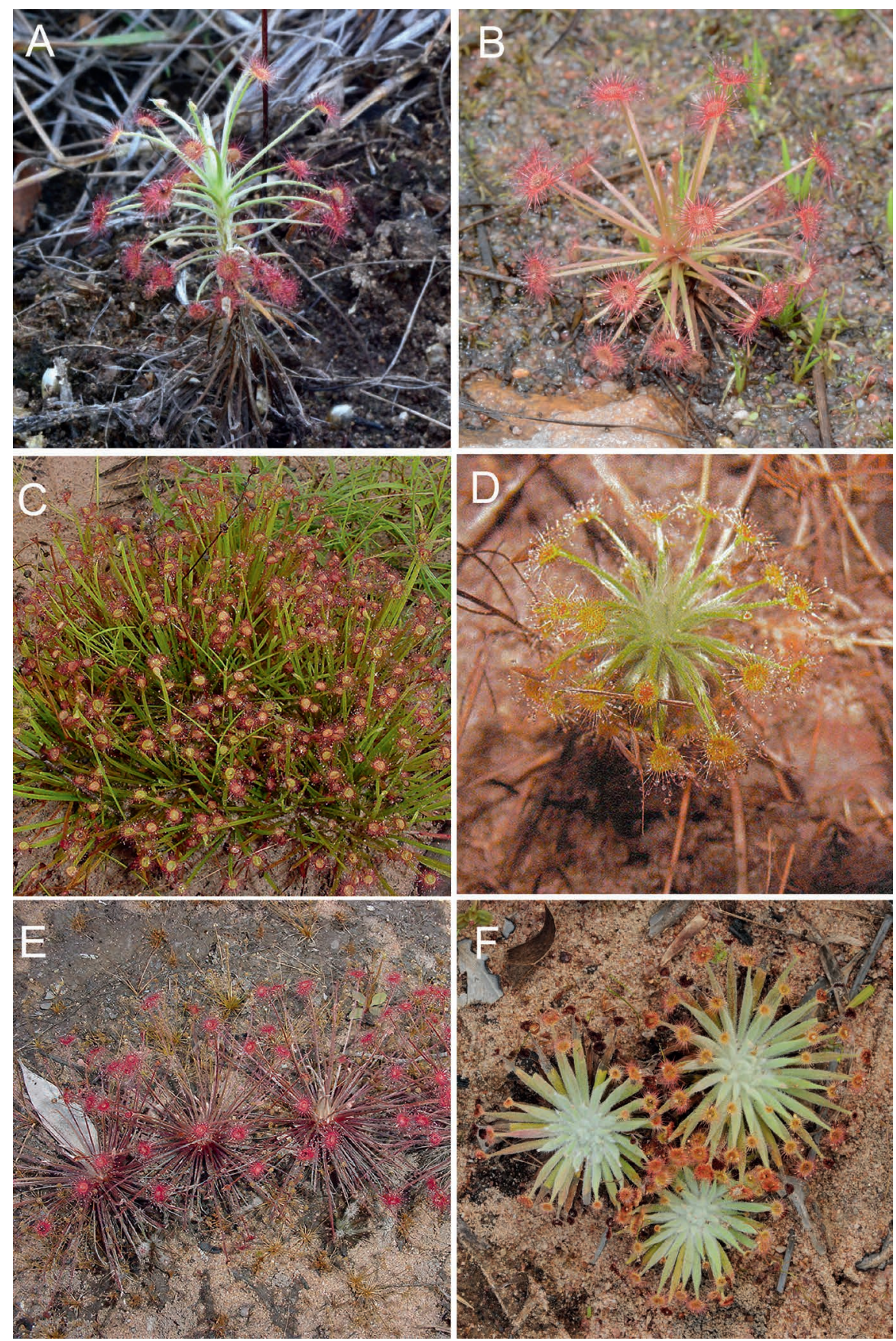

Figure 4: A: Drosera aff. paradoxa (Orange Flower) NT; B: D. aff. paradoxa (Swamp Form); C: D. aff. petiolaris from NT; D: D. species from Bigge Island; E: D. aff. petiolaris (Pin cushion); F: D. species from Tanami Desert. Photos: A, B, F - R. Nunn; C, E - A. Lowrie; D - T. Handasyde. 


\section{Drosera aff. lanata from NT (Fig. 3F)}

Only found in sandy habitats to the southeast of Darwin, Northern Territory. In the wet season, this species has few hairs covering its leaves in the wet season. By contrast, these same leaves are densely hairy, like those of $D$. lanata, in the dry season.

\section{Drosera aff. petiolaris from NT (Fig. 4C)}

The N.T. taxon is actually an undescribed species of perennial tropical Drosera. It has leaves up to $12 \mathrm{~cm}$ long and an inflorescence that has semi-erect pedicels $3-8 \mathrm{~mm}$ long. By contrast, type $D$. petiolaris from Queensland has leaves up to $6 \mathrm{~cm}$ long and an inflorescence with pendulous pedicels 1.5-2.5 mm long.

Drosera aff. petiolaris (Pin cushion) (Fig. 4E)

A clumping species bearing very narrow leaves that are both erect and semi-erect within each leafy rosette, appearing pin-cushion like overall.

\section{Drosera aff. paradoxa (Orange flower) (Fig. 4A)}

Drosera aff. paradoxa (orange flower) is distinguished from $D$. paradoxa by its overall smaller habit and metallic orange flowers, as well as its mostly annual habit in the wild. Drosera aff. paradoxa (orange flower) generally grows in very shallow skeletal soils over sandstone rock which dries out quickly with the onset of the dry season.

\section{Drosera aff. paradoxa (Swamp form) (Fig. 4B)}

Drosera aff. paradoxa (swamp form) is distinguished from D. paradoxa by its lack of an erect, woody stem on mature plants, its clumping habit, and preference for saturated, black silty soils in wet season flooded herb fields.

\section{The six seasons of tropical northern Australia}

Aboriginal Australians of the Northern Territory of Australia recognise six different seasons based on thousands of years of local knowledge (Parks Australia 2021). The transitions between seasons are marked by subtle variations in the weather, the plants in flower, and the bush foods that are most abundant. The tropical Drosera of section Lasiocephala have adapted in unique ways to survive this harsh and unforgiving climate.

\section{Kudjewk - Monsoon season}

December to March. $24^{\circ} \mathrm{C}-34^{\circ} \mathrm{C}$

This is the true tropical summer season. Thunderstorms, heavy rain and flooding prevail. The heat and humidity cause an explosion of plant life. Speargrass the dominant grass of northern Australia grows to over two metres tall and overall gives a silvery-green appearance to the woodlands.

Bangkerreng - 'Knock 'em down' storm season

\section{April. $23^{\circ} \mathrm{C}-34^{\circ} \mathrm{C}$}

By April the rain clouds have dispersed and clear skies prevail. The vast expanses of floodwater recede and streams start to run clear again and the land is marked by violent, windy storms that flatten the speargrass - these are called 'knock 'em down' storms. 
Yekke - Cooler (but still humid) season

May to mid-June. $21^{\circ} \mathrm{C}-33^{\circ} \mathrm{C}$

This is a relatively cool time with less humidity and dry winds. Early-morning mists hang low over the plains and to not only to thoroughly soak your bedding when camped out under the stars but also watering the rich and variable flora array of the herb fields each day.

\section{Wurrkeng - Cold weather season}

Mid-June to mid-August. $17^{\circ} \mathrm{C}-32^{\circ} \mathrm{C}$

This is the cold time by Tropical Northern Australian standards. Humidity is low, while daytime temperatures are around $30^{\circ} \mathrm{C}$ and drop to about $17^{\circ} \mathrm{C}$ at night. Most creeks stop flowing and the floodplains quickly dry out but are refreshed by the dew at night.

Kurrung - Hot dry weather season

Mid-August to mid-October. $23^{\circ} \mathrm{C}-37^{\circ} \mathrm{C}$

The country is hot and dry and dusty as the thunderclouds start to build.

Kunumeleng - Pre-monsoon storm season

Mid-October to late December. $24^{\circ} \mathrm{C}-37^{\circ} \mathrm{C}$

The pre-monsoon season's hot weather becomes increasingly humid. It can last from a few weeks to several months. Thunderstorms build in the afternoons and their showers bring green to the dry land.

\section{Dormancy and survival strategies}

The Tropical Drosera have developed some remarkable adaptations and clever strategies to maintain the wellbeing and good health of their life-forms. Stormy and cyclonic weather events, droughts, flooding, and fires are regularly encountered over their variable landform habitats each season. In every case each species has successfully evolved its own strategies to out-manoeuvre every one of these natural disasters.

Different Tropical Drosera species have evolved to utilise every form of habitat and landform across tropical northern Australia from east to west. From the driest desert areas of inland Australia to the wettest swamps and everywhere in between has been colonised by the tropical Drosera species of Australia. It is not uncommon to see examples of hilly landforms with a wet zone at the base of its hill where the soil types are lateritic loam on the summit of the hill, a mixture of sand and laterite soils on the downward scree slopes, and grey silty soils on the flat land immediately below the hill. Commonly in this landscape especially about the Darwin districts, one would commonly find: Drosera darwinensis towards the hills' summit; D. brevicornis on the scree slopes of the hill; and $D$. falconeri on the flatland in the grey silty soil.

The foliage of many species of tropical Drosera is covered by a hairy indumentum. Each hair can be entire or a branching (dendritic) hair. When these hairs are tightly packed together over the foliage, they produce a rather woolly appearance to all of the plant. In full dormancy the rosettes of these species dry back to their central parts to form a tight compact cluster of spent leaf bases that are still covered in the remains of their woolly indumentum. This adaptation strategy is remarkably fire proof against any passing fire event. Tropical northern Australia is commonly subjected to bush fires that are started by electrical storms' lightning strikes.

The very outer parts of the dormant rosette are sacrificed to the flames until the fire quickly passes over them and the central live parts of the plant are safe and protected from the flames. Ad- 
ditionally, this sacrificial outer spent leaf strategy produces a secondary cooling effect by dragging cooler air throughout the central parts of the rosette as the fire's heat rapidly rises and exits the burning rosette. The passing fire's fuel load quickly burns out the moment the outer sacrificial leaves have been burnt away.

In tropical northern Australia the seasonal burning of the country stimulates new and rapid grass growth. This method has been practiced seasonally by aboriginal man for eons to provide food to the grazing animals and also to congregate those same animals into the same area where they can be hunted easily for food. Cattlemen of tropical northern Australia within the same country also practice fire farming to promote new grass growth. They call it "green pick". Remarkably grass shoots appear in just a matter of a few short days after a burn.

One of us (A. Lowrie) has witnessed a large Drosera ordensis colony near Kununurra, WA, that had a vehicle track cut through the middle of the population. On one side of the track, it had been burnt by a grass fire, on the other side of the track it was unburnt because the track had acted as a fire break. All plants in the population were fully dormant and growing in dry sandy soil. Those plants outer parts on the burn side of the track were singed and blackened but still fully alive and starting to produce new leaf growth as well as producing flowering inflorescences. While those plants on the unburnt trackside were still fully dormant and showing no signs of any new growth. It appears fire or the chemicals from fire, is a natural stimulate for foliage growth.

Species having a woolly indumentum also are quite clever at using their hairy covering as a self-watering system. Utilizing the moisture derived from the early morning dews in the dry season, these species have the ability to harvest water for their needs. They do this by attracting moisture from the foggy morning air. Each hair tip captures a minute bead of moisture which in turn flows downward to join with other minute bead of moisture together accumulating into ever more large droplets that eventually drop to the soil surface as a large droplet and by default water the root zone base of the plant. Some of these woolly species especially those from those rather arid habitats also have many branching hairs along each individual hair within their indumentum. These dendritic hairs increase the area of moisture capture from the foggy air.

New root growth consists of a few water-filled fleshy rather fat parsnip-like roots that penetrate the soil at the start of the plant's new season growth cycle. Later in the season these same few fleshy roots lose their moisture and in turn revert to an extremely strong thin wire-like root that penetrated deep into the ground. Over many seasons these wire-like roots persist and it is not unusual to see when plants are removed from the soil a large number of these wire-like roots attached at the base of the plant. Together these roots anchor the plants to the soil strongly where they hold fast to the soil during any flooding event.

A different dormancy strategy, resting below the soil surface has been adopted by two species: Drosera falconeri and Drosera kenneallyi. Both of these species retreat to their compact bulb-like fleshy leaf bases. This structure can be likened to that same structure of Dionaea muscipula (Venus flytrap), simply a bulb-like accumulation of compact fleshy leaf bases that it uses as a dormancy adaptation.

Both of these species favour monsoon period flooded grey silty soils generally where grey magnetic ant mounds are often found. The bulb-like structure of these plants is positioned just below the soil surface, above which the leafy rosettes lay prostrate hard pressed to the soil surface. At the end of its leafy growth above the soil surface, the leaves are deciduous and the plants retreat to their bulblike bases below the soil surface. At this time these same saturated soils have dried out, hardened to the point where the soil has the consistency of an adobe brick. It is here cocooned in its concrete-like surrounds that it will spend its entire dormancy during the hot dry season and safe from any bushfires. 
The dormancy of tropical Drosera species is broken with the first rain showers during the build-up to the wet season. The annual species germinate quickly from seed and grow rapidly as a result of the available moisture and also the ability to capture and digest prey in the early stages of growth. Perennial Drosera develop new leaves quickly from the centre of the bulb-like structure, and in some species, the inflorescence is also produced at this time. From the first moment that moisture is available, the race is on to renew vegetative growth, build up reserves, flower and disperse seed. This urgency is necessary, as in some years, the wet season is short and sudden droughts occurs. At the beginning of the growing season new roots are produced. These roots are white, thick and fleshy, and hold a considerable amount of moisture. At the end of the season, these same roots become thin and fibrous. They then lack the fleshy structure needed to hold moisture and are simply employed to anchor the plant to the soil. It is not known whether these fibrous roots are still capable of absorbing moisture.

\section{Flowering}

Each inflorescence generally presents only one open flower at a time. The flower lasts one day whether pollinated or not. All species have inflorescences that support many flower buds. Additionally, each species produces more than one inflorescence. Drosera falconeri generally has an inflorescence supporting about 12 flowers, so the flowering period is short. $D$. fulva commonly produces three scapes up to $45 \mathrm{~cm}$ tall, each supporting inflorescences holding 50 plus flowers. The large number of flowers produced means that D. fulva can be found in flower from February through to May.

After the first monsoon rain, most of the tropical Drosera species produce their juvenile or somewhat advanced flowering inflorescences at the same time that they are also renewing their new season's leafy growth. Two species however, $D$. falconeri and $D$. kenneallyi, employ a totally different flowering regime. During the build-up (the pre-monsoon season), when the soil is still reasonably dry, both of these species start to flower well before any meaningful foliage is produced. They flower, are pollinated, and when spent get pushed over to the soil surface by the production of their new season leafy rosettes that have developed well after their flowering events have ended. The seed pods still attached to their spent inflorescences are still held in their seed capsules but are now covered by the leaves pressing them to the soil surface. Here they will remain until they are released when all leafy growth has dried out.

Drosera caduca is a strange species as it is only at its insect capture stage at the beginning of its seasonally new first growth and then only for a short period of time. After its carnivorous growth stage, it reverts to its non-glandular long grass like lamina. At this same time, it also produces its flowers. Later in the season all of this species foliage and all parts above the soil become deciduous and the plants retreat to a bulb-like structure made up of the fleshy bases of the foliage into their sandy soil habitat. Just the tips of these structures are at the soil surface where they remain while they are dormant. This species asexually reproduces itself and this results in large clumps growing in compact clusters. At the time of dormancy those plants derived from the mother plant have mostly detached from each other.

The colours of the flowers of the perennial tropical Drosera (Figs. 5A to 5D) vary from white through to dark pink and one still unnamed taxon has orange flowers. It is not uncommon for a particular species to have white and pink coloured flower forms. Morphologically, there are very few good floral characteristics that distinguish one species from the next. One exception is D. brevicornis, which has a strange, large, hook-like projection above each pair of anthers on all five stamens. Pedicel length and its position (erect, semi-erect, or pendulous) in fruit on the inflorescence can be used as a 


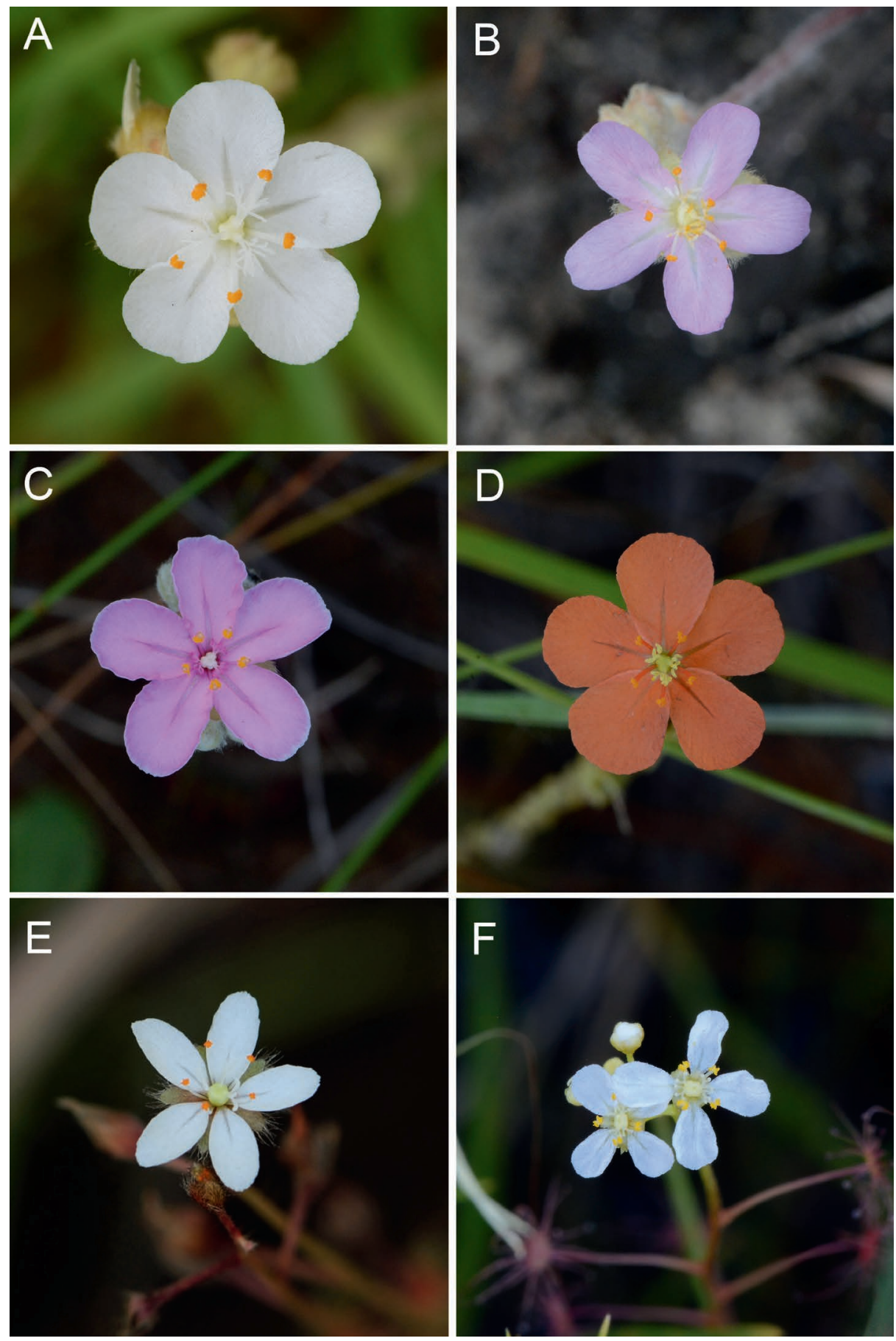

Figure 5: A: Drosera lanata; B: D. petiolaris; C: D. brevicornis; D: D. aff. paradoxa 'Orange flower'; E: D. banksii; F: D. subtilis. Photos: R. Nunn. 
characteristic to help distinguish one species from the next. Conversely, the hairy indumentum of the inflorescence appears to be similar amongst most named species in this complex. It should also be noted that this hairy covering is commonly mixed with dendritic hairs. Drosera broomensis is the only odd one out, with its glabrous scape and inflorescence. The flowers of the two annual species (Figs. 5E $\& 5 \mathrm{~F}$ ) are inconspicuous and white but have useful characters to easily identify each species.

Acknowledgements: The authors would like to thank Greg Bourke, Alastair Robinson, Paulo Baleeiro and Tricia Handasyde, for providing images without which this work would not be complete. Jan Schlauer and Andreas Fleischmann for reviewing the manuscript and providing many useful observations and comments.

\section{References}

Baleeiro P.C., Jobson, R.W., and Barrett, R.L. 2020. Drosera stipularis, a new species for the D. petiolaris complex from Cape York Peninsula, Queensland. Telopea 23: 35-40.

Bourke, G., and Nunn. R. 2012. Australian Carnivorous Plants. Redfern Natural History Productions Ltd.: Dorset, UK.

de Candolle, A.P. 1824. Prodromus systematis naturalis regni vegetabilis 1. Sumptibus Sociorum Treuttel et Wurtz: Paris.

Diels, F.L.E. 1906. Droseraceae. In: Engler, H.G.A. (ed.). Das Pflanzenreich 4: 1-136.

Fleischmann, A., Cross, A.T., Gibson, R., Gonella, P.M., and Dixon, K.W. 2018. Systematics and evolution of Droseraceae. In: Ellison, A.M., and Adamec, L. (eds.) Carnivorous Plants: Physiology, ecology, and evolution. Oxford University Press: Oxford. pp. 45-57.

Kondo, K. 1984. Three new species of Drosera L. from Australia. Boletim da Sociedade Broteriana 57: 51-60.

Lowrie, A. 1994. Drosera ordensis (Droseraceae), a new tropical species of carnivorous plant from northern Australia. Nuytsia 9: 363-367.

Lowrie, A. 1996a. Drosera kenneallyi (Droseraceae), a new tropical species of carnivorous plant from the Kimberley, northern Western Australia. Nuytsia 10: 419-423.

Lowrie, A. 1996b. New species in Drosera section Lasiocephala (Droseraceae) from tropical northern Australia. Nuytsia 11: 55-69.

Lowrie, A. 1997. Drosera paradoxa (Droseraceae), a new species from northern Australia. Nuytsia 11: 347-351.

Lowrie, A. 1998. Carnivorous Plants of Australia, Volume 3. University of Western Australia Press.

Lowrie, A. 2014. Carnivorous Plants of Australia, Magnum Opus, Volume 2. Redfern Natural History Productions Ltd.: Dorset, UK.

Lowrie, A., Robinson, A., Nunn, R., Rice, B., Bourke, G., Gibson, R., McPherson, S., and Fleishmann, A. 2017. Drosera of the World, Volume 2: Oceania, Asia, Europe, North America. Redfern Natural History Productions Ltd.

Marchant, N.G., and George, A.S. 1982. Drosera. In: George, A.S. (ed.). Flora of Australia 8. Canberra. pp. 9-46.

Parks Australia. 2021. Six Seasons. Australian Government, Kakadu National Park. https:// parksaustralia.gov.au/kakadu/discover/nature/seasons/

Planchon, J.E. 1848. Sur la famille des Droséracées. Annales des sciences naturelles. Botanique sér. 2 Sér. 3: 79-98, 185-207, 285-309.

Seine, R., and Barthlott, W. 1994. Some proposals on the infrageneric classification of Drosera L. Taxon 43: 583-589. 


\section{CARNIVOROUS PLANT NEWSLETTER}

Journal of the International Carnivorous Plant Society

Volume 50, No. 3

September 2021

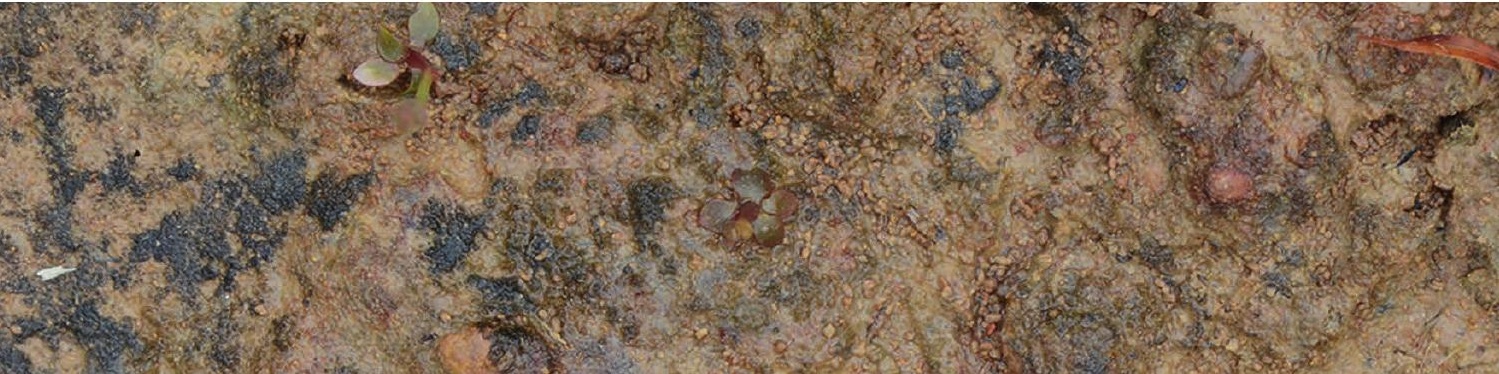

6hing:

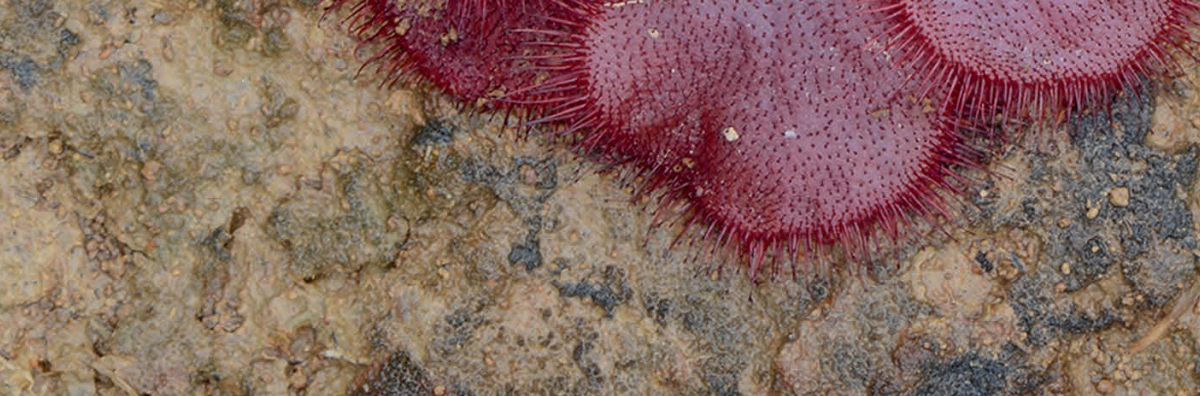

4

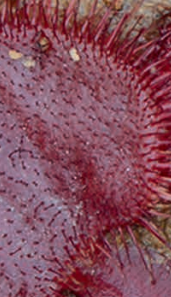




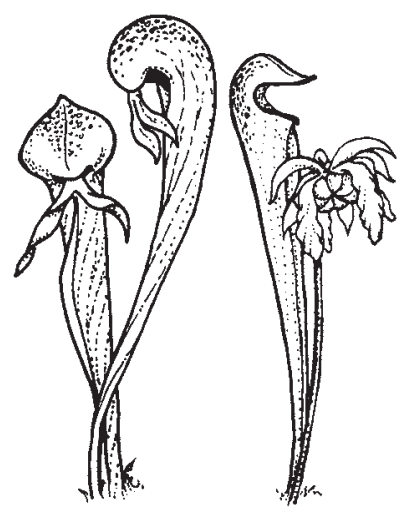

\section{CARNIVOROUS \\ PLANT \\ NEWSLETTER}

Journal of the International

Carnivorous Plant Society

www.carnivorousplants.org

\section{Volume 50, Number 3 September 2021}

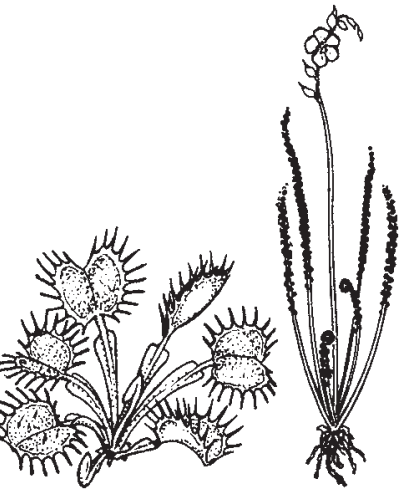

Front Cover: Drosera falconeri in full growth in the Darwin area, Northern Territory, Australia. Photo by R. Nunn. Articles on page 118 and 133.

Back Cover: Drosera fulva at the end of the wet season, growing at Noonamah, Northern Territory, Australia. Photo by R. Nunn. Article on page 118.

Carnivorous Plant Newsletter is dedicated to spreading knowledge and news related to carnivorous plants. Reader contributions are essential for this mission to be successful. Do not hesitate to contact the editors with information about your plants, conservation projects, field trips, or noteworthy events. Advertisers should contact the editors. Views expressed in this publication are those of the authors, not the editorial staff.

All correspondence regarding dues, address changes and missing issues should be sent to the Membership Coordinator at the ICPS. Do not send such correspondence to the editors. Checks for subscriptions should be made to the International Carnivorous Plant Society in US funds. Dues, including a subscription, are \$35 per year.

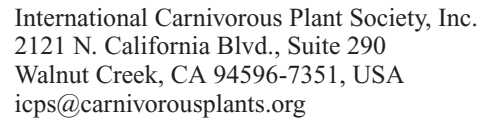

President

Vice President

Secretary

Treasurer

Board Member

Board Member

Board Member

Board Member

Board Member

Membership Coordinator

Webmaster

Media Coordinator

Seed Bank Manager

Facebook Manager
Richard Nunn, richardnunn@carnivorousplants.org

John Brittnacher, john@carnivorousplants.org

Cindy Slezak, cindy@carnivorousplants.org

Daniela Ribbecke, daniela@carnivorousplants.org

Kenny Coogan, Education Director, kenny@carnivorousplants.org

Brent Jones, brent@carnivorousplants.org

Jan Schlauer, Cultivar Registrar, jan@carnivorousplants.org

Carson Trexler, Conservation Director, carson@carnivorousplants.org

Bob Ziemer, bob@carnivorousplants.org

Cindy Slezak, cindy@carnivorousplants.org

John Brittnacher, john@carnivorousplants.org

Chad Williams, chad@carnivorousplants.org

Joe Griffin, joe@carnivorousplants.org

Marcel van den Broek, marcel@carnivorousplants.org
CPN Editors

Managing Editor

Editor

Editor

Editor editor@carnivorousplants.org
Bob Ziemer
Barry Rice
Karl Herold

John Brittnacher
Science Editor

Science Editor

Science Editor
Andreas Fleischmann

Fernando Rivadavia

Jan Schlauer

Date of effective publication of the June 2021 issue of Carnivorous Plant Newsletter: May 11, 2021.

The ICPS is the International Cultivar Registration Authority (ICRA) for the names of cultivated carnivorous plants according to the International Code of Nomenclature for Cultivated Plants. Send relevant correspondence to the ICPS, Inc.

Carnivorous Plant Newsletter is published quarterly in March, June, September, and December by the ICPS, Inc., 2121 N. California Blvd., Suite 290, Walnut Creek, CA 94596, USA. Periodicals postage paid at Walnut Creek, CA and additional mailing offices. Postmaster: Send address changes to ICPS, Inc., 2121 N. California Blvd., Suite 290, Walnut Creek, CA 94596, USA. Printed by Allen Press, Inc., 810 E. 10th Street, Lawrence, KS 66044. Logo and masthead art: Paul Milauskas. (C) 2021 International Carnivorous Plant Society. All rights reserved. ISSN \#0190-9215 